\title{
Retraction Note: Acute Toxicity and Gastroprotection Studies of a New Schiff Base Derived Manganese (II) Complex against $\mathrm{HCl} /$ Ethanol- Induced Gastric Ulcerations in Rats
}

\author{
Mohamed Yousif Ibrahim, Najihah Mohd Hashim, Summaya M. Dhiyaaldeen, \\ Mazen M. Jamil Al-Obaidi, Rashd M. El-Ferjani, Hoyam Adam, Bassam Alkotaini, \\ Rami Al Batran \& Hapipah Mohd Ali
}

Retraction of: Scientific Reports https://doi.org/10.1038/srep26819, published online 27 May 2016

The Editors have retracted this Article.

An investigation at the University of Malaya identified figure assembly and data integrity issues. Specifically, the following images were duplicated from a previous publication [1]: Fig. 6 G3 (Hsp70 stain, omeprazole (20mg/ $\mathrm{kg})$ ) and Fig. 6 G4 (Hsp70 stain, MDLA (500mg/kg)) were duplicates of Fig. 9E (HSP70 stain, omeprazole (20mg/ $\mathrm{kg})$ ) and Fig. 9C (HSP70 stain, HPTP $(50 \mathrm{mg} / \mathrm{kg})$ ), respectively. These issues undermine confidence in the study which cannot be considered reliable.

Najihah Mohd Hashim, Mazen Al-Obaidi, Bassam Alkotaini, and Rami Al Batran agree with the retraction. The other authors did not respond to correspondence about this retraction.

\section{Reference}

1. Dhiyaaldeen, S. M. et al. Protective effects of (1-(4-hydroxy-phenyl)-3-m-tolyl-propenone chalcone in indomethacin-induced gastric erosive damage in rats. BMC Vet Res 10, 961 (2014).

\begin{abstract}
(c) (i) Open Access This article is licensed under a Creative Commons Attribution 4.0 International License, which permits use, sharing, adaptation, distribution and reproduction in any medium or format, as long as you give appropriate credit to the original author(s) and the source, provide a link to the Creative Commons license, and indicate if changes were made. The images or other third party material in this article are included in the article's Creative Commons license, unless indicated otherwise in a credit line to the material. If material is not included in the article's Creative Commons license and your intended use is not permitted by statutory regulation or exceeds the permitted use, you will need to obtain permission directly from the copyright holder. To view a copy of this license, visit http://creativecommons.org/licenses/by/4.0/.
\end{abstract}

(C) The Publisher 2020 